\title{
The effects of mergers on the trade component of the balance of payments: The British evidence
}

\author{
A. Pouris \\ University of Cape Town, Department of Mechanical Engineering, Private Bag, Rondebosch 7700
}

Republic of South Africa

\begin{abstract}
This paper investigates empirically the effects of mergers within the British manufacturing industry on the trade component of the balance of payments. The effects of different merger rates over time on the trade component of the balance of payments are examined for the period 1880-1969. The effects of different merger rates over industry on the import/export performance of those industries are examined for the period 1969-1983. The results show that mergers had an adverse effect on the trade balance over the period 1880-1969 and that mergers did not determine the industries' performance over the period 1969-1983. It is argued that the neutral effects during the most recent period, are the result (actual and deterrent) of the Monopolies and Mergers Act 1965 and not due to similar merger movements in the main trade partner countries.
\end{abstract}

Hierdie artikel verteenwoordig 'n empiriese ondersoek na die uitwerking van samesmeltings binne die Britse vervaardigingsindustrie op die handelskomponent van die betalingsbalans. Die uitwerking van verskillende samesmeltings op die handelskomponent van die betalingsbalans word oor die periode 1880-1969 ondersoek. Die uitwerking van verskillende samesmeltingstempo's van die industrie op die vervoer/ uitvoerprestasie van daardie industrie, word ondersoek in die periode 1969-1983. Die resultate toon dat samesmeltings in negatiewe invloed op die handelsbalans tussen 1880 en 1969 gehad het en dat samesmeltings nie 'n uitwerking gehad het op die prestasie van die industrieè tussen 1969 en 1983 nie. Daar word bespiegel dat die neutrale uitwerking tydens die mees resente periode, die gevolg is van die Wet op Monopolieè en Samesmeltings van 1965, en nie as gevolg van soortgelyke samesmeltingsbewegings in die lande van die hoofhandelsvennote nie.

\section{Introduction}

One of the views, emphasized most often by the promoters of mergers, is that mergers improve efficiency and subsequently increase international competitiveness with beneficial effects for the balance of payments. (A distinction is often made between 'merger' and 'take-over' where the term 'merger' is used to describe the process of voluntary fusion between two or more companies, and the term 'take-over' usually means the acquisition of control through share purchase without the agreement of the directors of a company. For the purposes of this study, the term 'merger' is used in a generic sense, to refer to every kind of unification in firms.)

The importance of the issue has been recognized by the students of mergers (Reid, 1968; Hughes \& Sing, $1980)$ but the empirical evidence is limited, probably because of the unavailability of reliable data and the frequent implicit assumption, in the merger literature, that what is beneficial for a closed and isolated economy, is summum bonum for an open, trade-oriented nation.

In this article the British experience is investigated. The purpose is to examine the effects of mergers on the balance of payments by tracing the existence of any relationship between merger activity and the trade component of the balance of payments.

Firstly, the importance of the issue is outlined and the links between mergers and trade balance are analysed. Secondly, the methodology and the available data are discussed, and finally the statistical results and the conclusions are reported.

\section{Mergers and the balance of payments}

importance of the issue

In Neo-classical economics, the philosophy which underpins the scientific literature on the welfare implications of mergers, is that of the Pareto principle with its concern for the welfare of all individuals in society rather than with some organic concept of the state. On this basis, the empirical research is concentrated on a Williamson (1968) type model, and examines the trade-off between the efficiency gains through the exploitation of scale economies and the welfare loss due to increase of sellers' concentration and the enhanced opportunity for the exercize of market power.

The underlying assumption of the studies, based on the above philosophy, is that the economy is closed and in full employment. A consequence is that although a merger, which increases monopoly power but does not lead to economies of scale, will be considered as an unambiguous case of monopoly welfare loss by the orthodox equilibrium model, the conclusion will be invalid in a dizequilibrium economy. In such a case the economy is characterized by unemployed resources and balance of payments constraints and the merger could be beneficial if it generates extra benefits through exports or displacement of imports.

Although the importance of mergers for the balance of payments has received directly only scant attention by the researchers, the authorities for controlling the mergers and rationalizing the industry have recognized the problem and balance of payments considerations have been incorporated into the merger legislation all over the world.

The choice of the criteria used in judging mergers varies from country to country. Either the substantial lessening of competition which may result from a merger is considered in itself to be a sufficient criterion, or other criteria, such as the effects on the balance of payments, employment, prices, economies of scale, and so on are regarded as equally important. 
In Britain, the Board of Trade, within its powers given by the Monopolies and Mergers Act 1965 to investigate mergers, considers among others the following questions relevant to the balance of payments:

1. What are the export prospects in terms of each firm's current performance? Is the export record of each firm good compared with the rest of the industry - or with international firms? What proportions of output do they export? What is the structure of the international market? How large a share does the British industry hold? Is its main strength in preferential or non-preferential markets (e.g. USA, Germany)?

2. What is the dependence on imports? Is it likely to grow? Are there any implications for import substitution?

3. How far will reorganization and rationalization affect international competitiveness? Will overseas marketing organizations of the two companies be merged or nationalized? Is it the intention to build up overseas manufacturing activities? What is the expected balance in the overseas flow of funds of the combined range and variety of goods available?

4. Where a British company is involved in a merger with an overseas company, what are the balance of payments' consequences likely to be? Will there be any restriction on the British firm preventing its competing in markets of the overseas company? Will there be any transfer of manufacture out of the United Kingdom to the overseas company or its subsidiaries? Will the British firm in future, be required to import from abroad, e.g. components previously bought in the United Kingdom - or to alter its sources of imports? Where will effective management of the British firm rest, in the United Kingdom (with British nationals) or overseas? What are the consequences likely to be for the flows of technology and earnings from licensing? (Board of Trade, 1969)

Therefore, it can reasonably be assumed that mergers with promising results for the balance of payments will be viewed favourably by the Board of Trade, while mergers with harmful effects will be prevented.

\section{The Links}

Mergers have traditionally been seen by their proponents as an economical way of creating scale economies, eliminating bad management, reducing risk through diversification, and achieving greater technological progress. On the other hand, their opponents have argued that mergers increase concentration, reduce competition, induce allocative distortions, and give rise to $X$-inefficiency.

An account of the above arguments in connection with their effects on the balance of payments is given next. The most frequently stressed motive for mergers is the benefits which accrue from economies of scale. Intraplant technical economies of scale (e.g. automation) are irrelevant as the target firm almost always has its own plants, but inter-plant economies of scale stemming from pecuniary, marketing, managerial, and financial activities, are of the same nature as the single plant economies. Moreover, as Schrerer, Beckenstein, Kaufer \& Murthy (1975) suggest, transportation cost, special economies of labour inputs and dynamics of plant investments make the operation of several spatially dispersed plants more profitable than a single larger centralized plant.

The more profitable a firm is in a competitive environment, the more contribution it will make to the strengthening of the balance of payments and to other national economic objectives. Improvements in efficiency increase international competitiveness with beneficial effects for both the penetration of the foreign markets by exported goods and the displacement of imported goods by locally manufactured products.

Complementary to the achievement of economies of scale, mergers are often seen as a method for replacing inefficient management. In this traditional view, financiers and activist stock-holders are the parties who alone or in coalition with others buy control of a company and hire and fire management to achieve better resource utilization (Manne, 1965). Better resource utilization and 'takeover phobia' by the managerial teams increase efficiency and consequently international competitiveness.

Stabilizing earnings and sales via diversification is another reason for mergers, especially the conglomerate type. The argument is that by pulling imperfectly correlated income streams, a superior risk/return asset to the individual streams is created. However, the diversified character of the conglomerates could have ambiguous effects on the balance of payments.

When one of the merged firms already has expertise and experience on foreign markets, the merger could be seen as an opportunity for the other firm to acquire a foothold in the foreign markets. On the other hand, conglomerate mergers could be seen as an alternative to eliminate the risk of the 'business cycle' which, otherwise, would have to be eliminated through exports. A company could stabilize its earnings and sales either by entering into a different field of business or by exporting to a country with a different business cycle. Therefore, mergers could replace efforts for exports with an adverse effect for the trade balance.

Among the incentives for defensive diversification is the elimination of risk which arises when the firm undertakes Research and Development. Research and Development is a risky process and 'the only way within the private enterprise system to minimize this problem is the conduct of research by large corporations with many projects going on, each small in scale compared with the net revenue of the corporation. Then, the corporation acts as its own insurance company' (Arrow, 1962). Mergers increase the absolute size of the firms and according to Arrow's view, they will be able to intensify their activities on Research and Development. Increased expenditure on Research and Development could create new products which can have an appeal to foreign markets and could rationalize existing goods at home 
market where consumers may have turned to imports due to lack of adequate variety or high prices.

On the other hand, to accumulate sufficient liquidity for a takeover, a company may have to cut back on its own research and development or investment activities. Additionally, Scherer (1965) and Nordhaus (1969) have, contrary to Arrow, argued that the distribution of returns to research might well be so irreguiar, that the results of portfolio selection theory would not hold for the invention process.

Another advantage for young, small companies is that, because they have no large capital investment in a particular technology, they have little to fear and much to gain from trying a new course. Therefore, the effects of mergers via innovation on the balance of payments are theoretically undetermined as well.

Mergers can have an adverse effect on the balance of payments via the increase of sellers' concentration and the enhanced opportunity for the exercize of market power, and via the increase in the absolute size of the firm and enhanced opportunities for the pursuit and influence of political power.

Increased sellers' concentration creates oligopolies and monopolies and such market structures have been criticized as promoting $X$-inefficiency (Leibenstein, 1966). Leibenstein suggested that in imperfectly competitive situations, production costs would tend in practice to be higher than the minimum level which efficient production could achieve, largely as a result of management and workers substituting their own objectives (including a desire for a quiet life) for those of the equity interests. Although Parish \& $\mathrm{Ng}$ (1972) argued that the effect of $\mathrm{X}$-inefficiency is simply a redistribution where the 'increase in producer's surplus is taken out in leisure rather than in command over goods and services' the effect of this redistribution will affect adversely the balance of payments. Products in an oligopolistically structured market will have a higher production cost than in a competitive market, and consequently exports will suffer and local consumers will prefer imported cheaper products.

Large firms, in absolute terms, are usually associated with political power and influence. Large firms benefit from economies of scale in political influence production and mergers dilute the 'public' good nature of most policy outcomes and give incentives to firms to contribute to group efforts to influence public policy. Political influence can be directed towards entry-prevention policies both against new arrivals and imports. Entryprevention policies against possible competitors ensure the monopolist for his future power and facilitate a quiet life strategy with adverse effects for productivity, technological progress, and consequently the balance of payments. Policies against imports (tariffs, quotas, health regulations, pollution standards, etc.) can be beneficial, at least for a while (assuming that the partner countries will not retaliate), by replacing imports with domestic production. In the long run, however. these policies insulate the local firms from changing cnvironment abroad with adverse consequences for exports and eventually local demand, as local preferences might change responding to new improved products from abroad.

Finally, mergers are disadvantageous in relation to internal expansion in terms of productivity and consequently international competitiveness. Internal expansion will create a new plant which will adopt the most recent technology while an acquired plant will have already embodied a relatively old technology.

Summarizing, it seems apparent that mergers have contradicting effects on the balance of payments. Economies of scale and replacement of inefficient management could have a desirable effect, but creation of oligopolistic structures and influences on public policies may affect adversely the balance of payments. The question of what effect mergers have on the balance of payments remains an empirical one.

\section{Empirical estimation}

In this section the existence of a relationship between merger frequencies and changes in the current account in the United Kingdom are investigated. The appropriate methodology depends upon the quality and availability of data. Therefore, firstly the available data and their sources are discussed and then the methodology and the findings.

\section{Data}

\section{Statistics on mergers}

Researchers, investigating mergers, face two problems: The first is the availability and continuity of data and the second is the choice of the appropriate yardstick of the volume of merger activity for the specific purpose. Next, the way of handling these two issues is discussed.

Ideally, merger statistics are compiled by a government agency with the aid of statutory merger disclosure requirements and an efficient financial press. In the United Kingdom, there are reliable official statistics only from 1954 and onwards. However, important gaps exist in 1961 and 1969.

Between 1954 and 1961 (Economic Trends, 1963), the figures are related to companies with a stock exchange quotation and are based on the accounts of companies whose financial year ends within the 12 months to 5 April. Since 1961 (Staff of the Monopolies Commission, 1970 ), companies with assets of less than $f 0,5$ million or with income of $£ 50000$ or less were excluded. This reduced merger activity by an estimated $6,6 \%$ relative to earlier years. Another change in the data of this period (1954-1961) appears in publications after 1971, as the improved treatment of consolidations, introduced by the Department of Trade and Industry, has been applied retrospectively to these statistics, including mergerconsolidations, considering the larger firm as acquiror and the smaller as acquired.

In 1969 (Business Monitor) the basis of the official statistics changed from company accounts to reports in the financial press. This change enabled a number of improvements to he made. In particular, it was possible to date mergeis by the calendar year and the quarter in which the transaction was finalized rather than by the 
accounting year; to exclude acquisitions of foreign companies by the United Kingdom quoted companies, and to widen coverage to include more non-quoted companies.

A longer historical series of mergers in the United Kingdom was compiled by Hannah $(1972 ; 1974)$ and an attempt to link the series insofar as that is practicable was attempted by her (Hannah, 1976). The series is derived from business and industrial histories, year books, company accounts, and reports in the financial press and covers the period 1880-1969. The author recognizes the bravery of her attempt and points out that 'it would be surprising if the mist of history had not obscured some past merger activity which under modern conditions would have been recorded' (Hannah, 1976).

The most often used measures of merger activity are the number and the values of firm disappearances by merger. It is not obvious which of them is the most appropriate measure but the number of mergers is likely to be more accurate, especially for historical data, than a value index which usually rests on a mix of prices paid, market and nominal values and sometimes on arbitrary assumptions about unknown values. An advantage of a value index is that it reflects a higher figure if two companies with a market valuation of millions of dollars merge than if the merging companies are valued at only a few thousand dollars (a valuable characteristic for studies of the effects of mergers on concentration or on the growth of large firms). However, a number index reflects more adequately the number of independent decision-making units in the economy which decide to merge, the number of different technologies that are diffused, and the number of diversified interests that are amalgamated. Moreover, a number index has the advantage of being in constant terms at different points in time, while a value index has to be adjusted for inflation, share prices, and so on. For the above reasons in this study the 'number of mergers per year' series is used as a yardstick of merger intensity.

\section{Statistics on the balance of payments}

A nation's balance of payments is a systematic record of all its economic transactions with the outside world in a given year. Its main components are the current account, the capital account, and the official settlements account. Although mergers can affect the capital account (e.g. larger companies may be tempted to invest directly abroad), their main effects are on the current account.

The current account includes trade in goods (merchandise), trade in services, and transfer payments. The main categories of service transactions are travel and transportation, income and payments on foreign investments, and military transactions. Transfer payments refer to gifts made by individuals and the government to foreigners, and gifts received from foreigners. The merchandise or visible trade balance is the area in which mergers are expected to have the most apparent effect.

Because it has long been an important source of revenue to governments, visible trade provides more statistical material at an earlier date for most countries than any other economic activity. For the United Kingdom, although some figures start from 1275, according to Clark 'the real beginning of commercial statistics belong to the sixteenth and early seventeenth century' (Clark, 1938), for it was not until the late sixteenth century that customs figures began to be used to measure the balance of trade and thus to guide policy. Unfortunately, however, it was the standard practice until some time in the nineteenth century to record the aggregate values of trade in terms of officially fixed values for each commodity. Since these were not always kept up to date, the aggregates tended to become increasingly misleading as a representation of the actual values of imports and exports. Reliable statistics for the nineteenth and the first half of the twentieth centuries are covered by the estimates first of Imlah (1958) and subsequently of the Board of Trade. There are minor breaks in Imlah's series, but most severely criticized have been the estimates by the Board of Trade of the inter-war years which have been described as 'little more than the vaguest haphazard guessing, unworthy of this country and of the technical accomplishments of the man responsible for the task' (The Banker, March 1948). The earliest inherent defect in trade statistics, as a result of smuggling, is not prevalent after the middle of the nineteenth century, when the approach to free trade and effective policing rendered much of this activity redundant.

There are two forms for recording the external trade: the 'general' system of recording and the 'special' system. Under the 'general' system the data collected by Customs and Excise comprise all merchandise imported into or exported out of the United Kingdom, whether or not the goods are intended at the time of importation for use in the home market or for re-exportation and whether or not the exports are from customs bonded warehouses. Under the 'special' system the goods are recorded as trade when they move across the customs boundary. Therefore goods imported directly into a customs bonded warehouse are counted as imports under the 'general' system at the time the documents relating to the movement are received at the customs office, but under the 'special' system they are counted at the time that they leave the bonded warehouse to enter the market. If these bonded goods do not move across the customs boundary but are re-exported direct from the warehouse, then under the 'general' system they are included as exports (having previously been included as imports), but under the 'special' system they are not included in either imports or exports. The UK trade statistics have traditionally been compiled according to the 'general' system (since 1976 statistics have also been compiled on the special trade basis to meet certain EEC requirements), but in the case of the UK there is not a great deal of difference between these two methods of recording.

Another way of analysing the overseas trade performance and competitiveness, especially at industry level, is through indicators of changes over time in the penetration of the home market by imported goods and in the proportion of the home industries' products exported. 
The Department of Industry and Trade developed four 'industry performance ratios', two each for imports and exports for each industrial sector.

The definitions of these ratios are as follows:

$$
\begin{aligned}
& \text { Ratio } 1_{i}=\left[\frac{\text { Imports }}{\text { Home demand }}\right]_{i} \\
& \text { Ratio } 2_{i}=\left[\frac{\text { Imports }}{\text { Home demand and exports }}\right]_{i} \\
& \text { Ratio } 3_{i}=\left[\frac{\text { Exports }}{\text { Manufacturers' sales }}\right]_{i} \\
& \text { Ratio } 4_{i}=\left[\frac{\text { Exports }}{\text { Manufacturers' sales and imports }}\right]_{i}
\end{aligned}
$$

The first ratio measures the share of the home market which is captured by imports for a product group denoted $i$. However, this ratio does not take into account the extent of the domestic industry's involvement in export markets, a high level of which might be considered to compensate for a high level of imports. Allowance is made for this by the second ratio, which decreases as exports increase. Similarly, ratio 3 relates exports to total sales by home producers and it ignores the extent to which imports of the same products are finding their way into the home market. This is featured in ratio 4 . The ratios 2 and 4 having the same denominator (home demand + exports $=$ [manufacturers' sales + imports exports $]+$ exports $=$ Manufacturers' sales + imports) provide more direct information on the relative growth of imports and exports and the difference between the two measures has a meaning as an indicator of the trade gap in a particular sector in relation to the size of the sector. A further advantage of ratios 2 and 4 is that they are not distorted by the unavoidable inclusion of goods which are imported for subsequent re-exportation, as this component appears in both the numerator and denominator of each ratio. The ratios were first introduced for the years 1968 to 1976 by Wells and Imber (1977) and since May 1978 they have been published in the Business Monitor MQ12 which provides figures for 12 months at quarterly intervals for the latest two years.

\section{Other statistics}

The number of registered companies with a share capital in existence at the end of each year, has been taken from the Annual Abstract of Statistics (HMSO various) and from various 'Papers of the House of Commons'.

The number of reported mergers and acquisitions in each manufacturing industry group in the United States, for the period 1957-1965, has been received from various news releases by the Federal Trade Commission and has been presented by Reid (1968).

The number of reported mergers in each manufacturing industry group in West Germany, for the period 1958 - 1968, has been received from the discussion paper
No. 150 'Merger development and policy in West Germany since 1958' (Cable, 1979).

The wholesale prices index series for the United Kingdom with which the visible balance of payments is deflated in this paper, has been received from Mitchell (1975). There are discontinuities in the series when a new index has been spliced onto the old. For this analysis the index is rebased, with a new base as the year 1953.

\section{Methodology}

Here an attempt is made to estimate the effects of merger activity on the merchandise trade balance in the United Kingdom.

Although from a theoretical point of view there is no unambiguous expectation as far as the sign of the possible relationship is concerned, the filtering of merger activity through the merger and take-over legislation suggests that a bias towards a positive relationship should be expected, especially for the most recent period. Of course, there is a variety of criteria on which the desirability and acceptance of mergers are based, but a merger with an apparent adverse effect on the balance of payments will not fulfil these criteria and it will not be permitted to occur on this basis.

The effects of mergers on the visible trade balance are examined over time and then over industry.

\section{The effects of mergers over time}

To investigate the effects of mergers on the visible balance over time, the relationship between merger rates and the visible balance for the period 1881-1969 is examined. Merger rate is defined as the ratio of aggregate number of mergers in the country over a 5-year period to the number of firms with a share capital in existence in the middle of the 5-year period. The number of firms in existence in the middle of the 5-year period has been used as a proxy for the average number of firms in existence over the entire period. In order to take into account the expected positive association of merger frequencies with the number of firms in existence, the merger rate instead of the nett number of mergers that occurred is used. This association as expressed by the Kendal Rank correlation coefficient is found to be 0,23 for the period 1885-1918 and 0,74 for the period 1939-1962 (Pouris 1983).

The figures for the merchandise balance are the sum of the annual visible trade balance over 5-year periods, deflated at 1953 prices.

To compensate for the fact that the available data are not reliable in a parametric sense, the Spearman Rank correlation coefficient is used in order to investigate the existence and the degree of correlation between merger rates and the visible trade balance. The Spearman Rank correlation coefficient (RS) is a non-parametric measure of correlation and can be used with scores which are not exact, in any numerical sense, but which in effect are simply ranks. An additional merit is that the RS is 'distribution-free' and no assumption about the distribution of the population from which the scores under analysis are drawn is needed to be made. 
Apparently, the effects of mergers will become visible some time in the future, after the mergers have occurred. Immediately after the merger, the two firms will continue to act as separate units, holding onto their own clients and suppliers, their own technology, and their organizational form. However, as the firms are amalgamated the effects of their merger will become apparent. It has been estimated that organizational changes take up to 5 years, after the day of merger, to be completed.

To account for this phenomenon, the Spearman Rank correlation coefficients which connect the mergers which took place in the period $t$ with the visible balance in the periods $t, t+1, t+2$, and $t+3$, are estimated. Therefore, it will be possible to infer not only the immediate effects of mergers, but also their effects up to 15 years after the mergers have occurred.

Table 1 shows the correlation between merger rates and merchandise balance, for the current period and three 5-year future periods (lead 1,2 , and 3 ), as it is expressed by the Spearman Rank correlation coefficient. The $t$-ratios associated with the RS show that a strong relation exists between merger rates and the visible trade balance, ten and fifteen years after the mergers have taken place. The correlation coefficients for leads 2 and 3 (10 and 15 years) are statistically significant at the $99 \%$ and $97,5 \%$ confidence levels, respectively.

Having established that a relationship exists between merger rates and visible trade balance, from a methodological point of view, the problems of direction of causal flow and the spurious correlation fallacy should be examined. Fortunately, the long lapse of time between mergers and the changes in the trade balance leaves no doubt for the direction of causality. 'There is a lapse of time between cause and effect and in any event the effect cannot precede the cause in the flow of time' (Wold, 1966) and in that case it would be inappropriate to suggest that a disturbance in the visible balance caused a surge in mergers ten to fifteen years in the past.

The spurious correlation, or hidden factor fallacy, is a more troublesome concept. The problem is to determine whether or not a hidden variable accounts for the observed relationship between merger rates and trade balances. Statistical techniques alone cannot guarantee

Table 1 Spearman Rank Correlation Coefficients (RS) between merger ratios and merchandise balance in the United Kingdom (1881-1969)

\begin{tabular}{cccc} 
Lead & RS & $t$-ratio & Sample size \\
\hline 0 & $-0,18$ & $-0,73$ & 18 \\
1 & $-0,32$ & $-1,32$ & 17 \\
2 & $-0,60$ & $-2,80^{*}$ & 16 \\
3 & $-0,53$ & $-2,25^{* *}$ & 15
\end{tabular}

*Statistically different from zero at $99 \%$ confidence level for one-tailed test

** Statistically different from zero at $97,5 \%$ confidence level for one-tailed test that an observed non-experimental relationship is causal but some insight can be gained, either by trying other likely variables to see if any of them removes the observed association or by using cross-section analysis.

There is a variety of factors affecting the trade balance. Policy measures and resource discoveries are some of them. Similarly, merger frequencies are affected by the economic, political, and legal environment (Reid, 1968). Although the long lapse of time between cause and effect (in this relationship) eliminates a variety of factors which have a short-term effect and it indicates that the hidden factor should be of a structural character, there are not adequate proxies for the environmental factors that can affect merger frequencies and trade balance (e.g. legislation) and even if it were possible for a variable to proxy adequately some of the environmental factors, a tiresome research by historians would be required. Therefore, for additional evidence the cross-section analysis is implemented as another alternative.

\section{Cross-section study of mergers' effects}

The overwhelming advantage of the cross-section analysis over the time series analysis is that, because all observations are made at the same time, there is no problem of changes in conditions. A devaluation, for example, affects usually all the manufacturing industries (although in a different degree) and not only a particular sector.

To test the effects of mergers on the trade balance, a cross-section regression is performed. As independent variable the merger ratio - i.e. the ratio of aggregate number of mergers in each of the two-digit level of industry detail, over the period 1969-1973, to the number of firms in the industry in 1971 - is used, and as dependent variable the changes in 'industry performance ratios' from their values in 1971 to 1976 and 1981 (ratios in 1976 - ratios in 1971). The number of firms in the industry in 1971 is conceived as a proxy for the average number of firms in the industry over the entire period. Similarly, the 'industry performance ratio' in 1971, 1976, and 1981 are conceived as the averages of the periods 1969-1973, 1974-1978, and 1979-1983 respectively. If mergers have a beneficial effect on the trade balance, a negative relationship should exist between merger rates and changes in 'import penetration ratios' (ratios 1,2 ) and/or a positive relationship between merger rates and changes in 'export proportions ratios' (ratios 3, 4). Beneficial mergers would reduce the share of the home market captured by imports and/or would increase the exports of home-made goods. Apparently, the opposite will be true for harmful mergers.

Table 2 shows the statistical results of the relationship between merger rates and changes in 'industry performance ratios' for periods of 5 and 10 years after the mergers have occurred. The $t$-statistic shows that the slope is not statistically different from zero for any of the ratios. Therefore, merger rates have no effect on the 'industry performance ratios' and consequently on the trade balance. 
Table 2 Results of cross-section regressions of merger rates and changes in industry performance ratios (IPRs) for the periods $1971-1976$ and $1971-1981^{\mathrm{a}}$

\begin{tabular}{cccccc} 
IPR & Period & Slope & t-stat. & $\begin{array}{c}\text { Coef. of } \\
\text { deter. }\end{array}$ & $\begin{array}{c}\text { Size of } \\
\text { sample }\end{array}$ \\
\hline 1 & $1976-71$ & 0,002 & 0,063 & 0,0003 & 14 \\
2 & $1976-71$ & 0,008 & 0,250 & 0,0051 & 14 \\
3 & $1976-71$ & 0,004 & 0,198 & 0,0032 & 14 \\
4 & $1976-71$ & 0,000 & 0,005 & 0,0000 & 14 \\
1 & $1981-71$ & $-0,002$ & 0,035 & 0,0001 & 14 \\
2 & $1981-71$ & $-0,001$ & 0,032 & 0,0000 & 14 \\
3 & $1981-71$ & 0,018 & 0,644 & 0,0334 & 14 \\
4 & $1981-71$ & 0,010 & 0,692 & 0,3830 & 14 \\
\hline
\end{tabular}

The examined relationships are of the functional form $Y=f(M)$ where $Y=$ change in industry performance ratios over the period shown in column 2 , and $M=$ merger rates, Jan. 1969-Dec.1973.

One possibility is that the restructuring of the British industry through mergers has been matched by similar movements in the main partner countries and therefore any beneficial or harmful effect has been neutralized. To examine this possibility, the number of mergers in the two-digit level of industry detail that occurred in Britain during the period 1961-1968 was compared with that which occurred in the United States and in West Germany. It was found that the distribution of mergers in the United States and West Germany does not match the distribution of mergers in the United Kingdom. The Spearman Rank correlation coefficients are 0,272 and 0,448 for the United States and West Germany, respectively, with 14 observations and these figures are not statistically significant at the 0,5 level of significance. Therefore it is concluded that the effects of mergers in Britain are not neutralized by similar events in the main partner countries.

Summarizing, when the effects of mergers over time were examined, it was found that there was a negative relationship between merger rates and the trade balance whilst, when the effects of mergers over industry were examined, it was revealed that merger rates do not affect the 'industry performance ratios'.

The two results can be reconciled by taking into account the difference in the time periods under examination. The time series study covers the period $1880-1969$ while the cross-section study is restricted to the period 1963-1984, owing to the unavailability of data. The important difference in the two periods is the increase in the second period in the public awareness and concern for mergers and subsequently the development of leqislation to permit only the beneficial mergers to occur. The problem became apparent in 1949 when a report of the Royal Commission expressed anxiety about the trend towards concentration in the industry. The situation was exacerbated in December 1961 when the possibility of an ICI-Courtaulds merger alarmed the public and finally the Labour Government of 1964-1970 with one voice charged the Monopolies and Mergers Commission with controlling the concentrated industries and the announced mergers.

The introduction of a mechanism which discriminates and permits only beneficial mergers (one of the criteria is the effects on the balance of payments) apparently introduces a bias and it should be expected that the permitted mergers would have a beneficial or at least neutral effect. Therefore, with strengthened anti-merger policy, during the period of this cross-section study, it is reasonable to argue that uncontrolled mergers (time series study) have a harmful effect on the visible balance of payments.

\section{Conclusions}

The main results of the present study can be summarized as follows:

1.A negative relationship between merger rates and the trade balance in the United Kingdom is present during the period 1880-1969. The adverse effect has a long gestation period and becomes evident 10 to 15 years after the mergers have occurred.

2.Merger rates were found to have no effect on the 'industry performance ratios' for the period $1969-1983$ on a cross-section study over 14 industries in the two-digit level of industry detail.

3.The above results are interpreted as being consistent with the hypothesis that uncontrolled mergers are harmful for the visible balance of payments. This interpretation is based on the argument that the increasingly restrictive legislation during the latest period has discouraged some of the mergers which could have had a harmful effect on the balance of payments.

These findings are suggestive, although tentative in nature. However, mergers have been found, in no time period, to have fulfilled the promises of their promoters for a beneficial effect on the trade balance. Investigations of the pre- and post-acquisition export and import substitution performance of merging firms, and case studies are required to give additional evidence of the effects of mergers on the balance of payments.

\section{References}

Arrow J.K.1962. Economic welfare and the allocation of resources for invention. In: The value and direction of 
inventive activity. National Bureau of Economic Research: Princeton University Press.

Board of Trade.1969. Mergers - a guide to Board of Trade practice London: HMSO.

Board of Trade Journal. 1969. London: HMSO.

Business Monitor MQ7.Various. Acquisitions and mergers of industrial and commercial companies. HMSO.

Cable J.1979. Merger development and policy in W.Germany since 1958. Discussion Paper No. 150. University of Warwick and International Institute of Management, Berlin.

Clark G.N.1938. Guide to English commercial statistics 1696-1782. London.

Economic Trends.1963. Acquisitions and amalgamations of quoted companies 1954-1961.

Hannah L. 1972. The political economy of mergers in manufacturing industry in Britain between the wars. Unpublished D.Phil. thesis, Oxford University.

Hannah L.1974. Mergers in British manufacturing industry 1880-1918. Oxford Economic Papers. vol.126.

Hannah L.1976. The rise of the corporate economy. London: Methuen \& Co Ltd.

Hughes A.L. \& Sing A.1980. Mergers concentration and competition in advanced capitalist economies: An international perspective. In Meuller D.C. (ed.) The determinants and effects of mergers. Cambridge, Mass.: OG\&H Inc.

Imlah H.1958. Economic elements in the Pax Britannica. Cambridge, Mass. : Harvard University Press.
Leibenstein H.1966. Allocative efficiency versus $X$-efficiency. Am. Econ. Rev. 392-415.

Manne H.1965. Mergers and the market for corporate control. $J$. of Polit. Econ. vol.73, 110-120.

Mitchell B.R.1975. European historical statistics 1750-1970. The MacMillan Press Ltd.

Nordhaus W.D.1969. Invention, growth and welfare. Cambridge, Mass.: MIT Press.

Parish R. \& Ng Y.K.1972. Monopoly, X-efficiency and the Measurement of welfare loss. Economica. vol.39, 301-308.

Pouris A.1983. Mergers and the economic disturbance theory. Unpublished MSc. dissertation, University of Surrey, p.90.

Reid S.R.1968. Mergers, managers and the economy. McGraw Hill.

Scherer F.M.1965. Firm size, market structure, opportunity and the output of patented inventions. Am. Econ. Rev.

Scherer F.M., Beckenstein A., Kaufer E. \& Murthy R.D. 1975. The economics of multiplant operation: An international comparisons study. Cambridge, Mass.: Harvard University Press.

Staff of the Monopolies Commission.1970. A survey of mergers 1958-1968. Department of Trade and Industry.

Wells J.D. \& Imber.1977. The home and export performance of the United Kingdom industries. Econ. Trends.

Williamson O.E.1968. Economies as an antitrust defence: The welfare trade offs. Am. Econ. Rev. vol.58, 18-36.

Wold H.O.A.1966. On the definition and meaning of causal concepts. In Wold H.O.A. (ed.) Model building in the human sciences. Monaco Centre International d'Etude des Problemes Humains. 